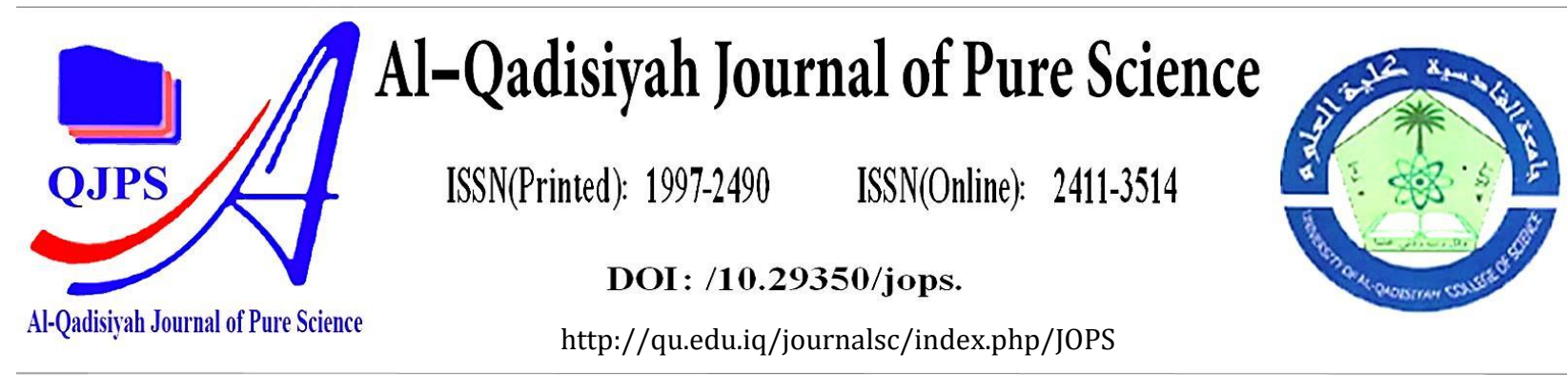

\title{
Grape seed extract role against L-Thyroxine effects on thyroid gland and lipid profile
}

\begin{tabular}{|c|c|}
\hline Authors Names & ABSTRACT \\
\hline $\begin{array}{l}\text { b. Dalal Turki Shattnan } \\
\text { Article History } \\
\text { Received on: } 28 / 6 / 2021 \\
\text { Revised on: } 12 / 7 / 2021 \\
\text { Accepted on: } 13 / 7 / 2021\end{array}$ & $\begin{array}{l}\text { The aim of the current study is identify role grape seed extract on thyroid } \\
\text { gland tissues, hormones and lipid profile disorders induced by L-Thyroxine by } \\
\text { used dose } 20 \mathrm{mg} / \mathrm{kg} \text {. The experience including } 40 \text { male rats randomly divided } \\
\text { into five groups each group consist of } 8 \text { animals, grape seed extract dose } \\
150 \mathrm{mg} / \mathrm{kg} \text { daily for } 30 \text {-day. }\end{array}$ \\
\hline $\begin{array}{l}\text { Keywords: } \\
\text { Grape seed extract, L- } \\
\text { Thyroxine, Thyroid } \\
\text { hormones, lipid profile, } \\
\text { hyperthyroidism, } \\
\text { antioxidant } \\
\text { DOI: } \\
\text { https://doi.org/10.29350/ jops. } \\
\text { 2021.26. 4.1408 }\end{array}$ & $\begin{array}{l}\text { Results Showed that the animals treated with L-Thyroxine had significant } \\
\text { increase }(\mathrm{P}<0.05) \text { in thyroid hormones concentration and decrease TSH } \\
\text { hormone compared with their normal range level in the control group and the } \\
\text { rest of the experiment groups, While groups in which grape seed extract (GSE) } \\
\text { interferes with drug showed improvement in thyroid hormones level closer to } \\
\text { normal range in control group. Also the results showed significant decrease } \\
(\mathrm{P}<0.05) \text { in TC, TG HDL, vLDL and in L-Thyroxine group, in addition to thyroid } \\
\text { tissue damage. On the other hand animals treated by both grape seed extract } \\
(\text { GSE) and drug showed significant improvement }(\mathrm{P}<0.05) \text { in TC, TG, HDL, } \\
\text { vLDL, LDL and thyroid tissue compared with groups treated with drug only. It } \\
\text { was concluded from this study that grape seeds extract had protective role } \\
\text { against damage caused by L-Thyroxine }\end{array}$ \\
\hline
\end{tabular}

\section{Introduction}

Thyroid common largest endocrine gland in the body, it's shape resembles butterfly on both sides of the trachea, Thyroid hormones plays an important role in regulation metabolism in all cells of the body, Thyroid hormone T4 ( L-3,5,3,5-tetraiodothyronine and T3 (L-3,5,3-triiodothyronine) responsible for regulation of proteins, fats and carbohydrates metabolism (4), and doing its functioning on the cells by thyroid stimulating hormone receptor TSHR that find on the cells DNA (18). Any disorders occurs in thyroid hormones (hypo- hyperthyroidism ) led to disorders in the cells function of the body (9).

L-Thyroxine and Carbimazole known as drugs to treat thyroid disorders it is also experimentally used to induce hypothyroidism and hyperthyroidism in laboratory animals (15). L-thyroxine drugs have 
an effect on oxidative stress and effect on lipid profile (TC, TG, HDL, LDL, vLDL)(13-1). In addition it is may be causes damages in the tissue of the thyroid gland (6). In the other hand Grape seed extract GSE has a major role in free radicals resistance that led to oxidative stress(17), as well as protecting cells from the toxic (14), so that, this study research in the ability of therapeutic grape seed extract in reducing the side effects on the thyroid gland and lipid profile that occur due to L-Thyroxine drug or hyperthyroidism.

\section{Materials and Methods}

Experiment design: In this study 40 male rats 200-250g weight, 3-4 months age divided into five groups each group consisted of 8 rats, (C) group considered as control given $1 \mathrm{ml}$ of distilled water for 45 day, (T1) first group given orally dose of L-Thyroxine $20 \mathrm{mg} / \mathrm{kg}$ daily for 45 day to induce hypothyroidism, (T2) second group

Given orally dose of GSE $150 \mathrm{mg} / \mathrm{kg}$ daily, (T3) third group given orally dose of L-Thyroxine $20 \mathrm{mg} / \mathrm{kg}$ for fifteen days then given oral dose of L-Thyroxine $20 \mathrm{mg} / \mathrm{kg}$ and GSE $150 \mathrm{mg} / \mathrm{kg}$ daily for 30 day, (T4) fourth group given oral dose of L-Thyroxine $20 \mathrm{mg} / \mathrm{kg}$ for fifteen days then given oral dose carbimazole $30 \mathrm{mg} / \mathrm{kg}$ to the end of the experiment for the purpose of comparing the ability of the grape seed extract and the drug to resist the negative effects of L-Thyroxine .

Chemicals: Used L-Thyroxine drug to induce hypothyroidism dose $20 \mathrm{mg} / \mathrm{kg}$ it is a common drug for the group of hypothyroidism.

Plant extract: In the present study local Iraqi Grape fruits purchased from local Iraqi markets, Seeds were isolated and dried in the shade, then grinded into an electric mixer to get a powder for use in the soxhlet apparatus for a water extract of grape seeds.

\section{Results}

Notes through the results table(1) that the animals treated with L-Thyroxine in the first and the third groups had a significant increase $(\mathrm{P}<0.05)$ in the concentration of thyroid hormones(T3, T4) compared with their normal range level in the control group and the rest of the experimental groups, also TSH significant decrease $(\mathrm{P}<0.05)$ in the first group compared with their normal range level in the control group and the rest of the experimental groups, while TSH significant differences $(\mathrm{P}<0.05)$ in third group compared with the first group.

In table(2) and table(3) results showed significant decrease $(\mathrm{P}<0.05)$ in $\mathrm{TC}, \mathrm{TG}, \mathrm{HDL}$, vLDL parameters in L-Thyroxine group compared with control and GSE group also the results showed significant decrease $(\mathrm{P}<0.05)$ in $\mathrm{TC}, \mathrm{TG}, \mathrm{HDL}$ concentration in forth group compared with control.

On the other hand in GSE group result showed that there is significant decrease $(\mathrm{P}<0.05)$ in TC, HLD, LDL and increase vLDL compared with control, while animals treated with L-Thyroxine and GSE in third group showed significant increase $(\mathrm{P}<0.05)$ in $\mathrm{TC}, \mathrm{HDL}$, vLDL compared with control and the first group which treated with L-Thyroxine only.

\section{Discussion:}

\section{Effect of L-Thyroxine and GSE in (TSH, T4, T3).}

L-Thyroxine it is drug an alternative to thyroid hormone T4 and has the same mechanical function as thyroxine hormone, which changes in tissue to T3, also high dose from the drug causes the effects of hyperthyroidism, it is therefore used to develop hyperthyroidism in laboratory animals and that make the 
concentration of T4 and T3 hormones high in the first group (10). In forth group decrease concentration of T4 and T3 hormones compared with the first group, that maybe due to known mechanism of carbimazole to inhibit peroxidase enzyme TPO action which it an important enzyme in the synthesis of thyroid hormones (8). Third group in which grape seed extract(GSE) interferes with drug, so that maybe explain the reason that $\mathrm{T} 4$ hormone level in this group closer to normal rang than its level in the first group maybe due to GSE flavonoids, Flavonoids have the ability to inhibit the action of and D1 deiodinase enzyme that converts T4 to T3 in liver this arise the level of T4 $(7,16)$. What mention above may explain that there is an decrease in the level of the TSH hormone reached to the significant degree $(\mathrm{P}<0.05)$ in the first group compared with the control, while it did not in the third group, Because it is known that there is an inverse relationship between the level of hormone TSH and the level of thyroid hormones according to the negative feedback mechanism (7).

Table(1):Effect of grape seed extract and L-Thyroxine in TSH, T3, T4 level.

\begin{tabular}{|c|c|c|c|}
\hline $\begin{array}{c}\text { TSH } \\
\mu \mathrm{IU} / \mathrm{ml}\end{array}$ & $\begin{array}{c}\mathrm{T} 4 \\
\mathrm{nmol} / \mathrm{l}\end{array}$ & $\begin{array}{c}\text { T3 } \\
\mathrm{nmol} / \mathrm{l}\end{array}$ & $\begin{array}{c}\text { Parameter } \\
\text { Groups }\end{array}$ \\
\hline $\begin{array}{c}0.02 \pm 0.163 \\
A\end{array}$ & $\begin{array}{c}2.53 \pm 83.66 \\
B\end{array}$ & $\begin{array}{c}0.21 \pm 2.47 \\
B\end{array}$ & control \\
\hline $\begin{array}{c}0.03 \pm 0.103 \\
C\end{array}$ & $\begin{array}{c}3.87 \pm 100.33 \\
A\end{array}$ & $\begin{array}{c}0.21 \pm 3.02 \\
A\end{array}$ & T1 \\
\hline $\begin{array}{c}0.09 \pm 0.155 \\
A\end{array}$ & $\begin{array}{c}2.43 \pm 84.78 \\
B\end{array}$ & $\begin{array}{c}0.18 \pm 2.23 \\
B\end{array}$ & $\mathrm{~T} 2$ \\
\hline $\begin{array}{c}0.01 \pm 0.135 \\
B\end{array}$ & $\begin{array}{c}1.21 \pm 94.66 \\
A B\end{array}$ & $\begin{array}{c}0.11 \pm 2.94 \\
A\end{array}$ & T3 \\
\hline $\begin{array}{c}0.01 \pm 0.165 \\
A\end{array}$ & $\begin{array}{c}1.54 \pm 80.00 \\
B\end{array}$ & $\begin{array}{c}0.15 \pm 2.33 \\
B\end{array}$ & $\mathrm{~T} 4$ \\
\hline $\begin{array}{c}0.02 \pm 0.163 \\
A\end{array}$ & $\begin{array}{c}2.53 \pm 83.66 \\
B\end{array}$ & $\begin{array}{c}0.21 \pm 2.47 \\
B\end{array}$ & LSD \\
\hline
\end{tabular}

* Number :mean \pm SE

Table(2): effect of grape seed extract and L-Thyroxine in Cholesterol and Triglyceride.

\begin{tabular}{|c|c|l|}
\hline $\begin{array}{c}\text { Triglyceride } \\
\mathrm{mg} / 100 \mathrm{ml}\end{array}$ & $\begin{array}{l}\text { Cholesterol } \\
\mathrm{mg} / 100 \mathrm{ml}\end{array}$ & $\begin{array}{l}\text { Parametre } \\
\text { groups }\end{array}$ \\
\hline $\begin{array}{c}0.65 \pm 36.6 \\
\mathrm{~A}\end{array}$ & $\begin{array}{c}0.48 \pm 51.66 \\
\mathrm{~B}\end{array}$ & Control \\
\hline $\begin{array}{c}0.48 \pm 26.66 \\
\mathrm{C}\end{array}$ & $\begin{array}{c}1.09 \pm 41.00 \\
\mathrm{C}\end{array}$ & $\mathrm{T} 1$ \\
\hline $\begin{array}{c}2.66 \pm 36.93 \\
\mathrm{~A}\end{array}$ & $\begin{array}{c}1.79 \pm 43.33 \\
\mathrm{C}\end{array}$ & $\mathrm{T} 2$ \\
\hline $\begin{array}{c}0.83 \pm 36.00 \\
\mathrm{~A}\end{array}$ & $\begin{array}{c}0.83 \pm 55.00 \\
\mathrm{~A}\end{array}$ & $\mathrm{~T} 3$ \\
\hline $\begin{array}{c}0.36 \pm 31.66 \\
\mathrm{~B}\end{array}$ & $\begin{array}{c}0.73 \pm 42.33 \\
\mathrm{C}\end{array}$ & $\mathrm{T} 4$ \\
\hline 2.38 & 1.71 & $\mathrm{LSD}$ \\
\hline
\end{tabular}

- Number :mean \pm SE 
Table(3): effect of grape seed extract and L-Thyroxine in HDL, LDL and vLDL

\begin{tabular}{|c|c|c|c|}
\hline $\begin{array}{l}\mathrm{vLDL} \\
\mathrm{mg} / 100 \mathrm{ml}\end{array}$ & $\begin{array}{l}\mathrm{LDL} \\
\mathrm{mg} / 100 \mathrm{ml}\end{array}$ & $\begin{array}{l}\mathrm{HDL} \\
\mathrm{mg} / 100 \mathrm{ml}\end{array}$ & $\begin{array}{l}\text { Parameter } \\
\text { groups }\end{array}$ \\
\hline $\begin{array}{l}0.24 \pm 6.06 \\
B\end{array}$ & $\begin{array}{c}0.16 \pm 22.94 \\
A\end{array}$ & $\begin{array}{c}0.86 \pm 22.63 \\
B\end{array}$ & Control \\
\hline $\begin{array}{c}0.63 \pm 5.33 \\
\mathrm{C}\end{array}$ & $\begin{array}{c}0.95 \pm 20.86 \\
A B\end{array}$ & $0.41 \pm 14.80$ & T1 \\
\hline $\begin{array}{c}0.81 \pm 7.38 \\
A\end{array}$ & $\begin{array}{c}2.08 \pm 18.49 \\
B\end{array}$ & $\begin{array}{c}0.14 \pm 17.56 \\
C\end{array}$ & $\mathrm{~T} 2$ \\
\hline $\begin{array}{l}0.30 \pm 7.20 \\
A\end{array}$ & $\begin{array}{c}1.45 \pm 22.96 \\
A\end{array}$ & $\begin{array}{c}1.03 \pm 24.83 \\
A\end{array}$ & T3 \\
\hline $\begin{array}{l}0.13 \pm 6.33 \\
B\end{array}$ & $\begin{array}{c}0.53 \pm 20.96 \\
A B\end{array}$ & $\begin{array}{c}0.34 \pm 15.06 \\
D\end{array}$ & T4 \\
\hline 0.47 & 1.86 & 1.03 & LSD \\
\hline
\end{tabular}

* Number :mean \pm SE

\section{Effect of L-Thyroxine and GSE in lipid profile.}

The significant reduction in cholesterol, triglycerides, HDL and vLDL was the first treatment, The interpretation of the results based on the association between hyperthyroidism and the decrease in the concentration of lipoproteins is the increase in lipoprotein receptors and explained the effect of thyroid hormones and their role in accelerating vLDL destruction $(13,1)$. The increase in lipoprotein lipase and hepatic TG lipase activity may result in a decrease in the concentration of bilirubin leads to a decrease in digestion and absorption of cholesterol, This is also a reason for the low concentration of cholesterol that the body gets from food despite high intake of food (11).

The reduction of thyroid hormones by carbimazole for the fourth group may led to an increase in the concentration of TG and vLDL but did not show any improvement in the concentration of cholesterol and HDL compared with the control, This may be explained the effect of carbimazole on the thyroid and reduce its production of thyroxine (3), on the other hand this group through the daily observation began to decrease appetite for food and we suggest that probably leads to decrease concentration of cholesterol that the body gets from food, in addition carbimazole also damages the digestive system and thus affects digestion and absorption, and may result in a decrease in the proportion of cholesterol that the body gets from food (2).

The improvement and increase in the concentration of cholesterol, triglycerides, and lipid proteins of the third group compared to the first group maybe back to the role of flavonoids a high percentage of grape seed extract, its reducing the efficiency of the enzyme deiodinase D1 in the liver and responsible for the conversion of T4 to T3 and thus decrease its concentration and then return the metabolism to its normal level and from which low consumption of high cholesterol (5), also rutin one of the compounds flavonoids which are vehicles in polyhydroxyphenolic compounds, this compound have able to reduces activity of peroxidase TOP so there is no increase in the concentration of thyroid hormones in the blood and the study demonstrated the ability of the complex of Rutin to reduce the effectiveness of the enzyme D1 deiodinase thereby reducing the concentration of T3, on the other hand the effectiveness of the brain enzyme D2 deiodinase not affected by rutin compound and this maintained TSH in normal concentration while $\mathrm{T} 3$ was reduction in the blood (7). 


\section{REFERENCES}

1. Alterihy F, Shemran K, Alta'ee A, Jabuk S. The association between thyroid hormones and lipid profile in patients with primary hyperthyroidism. Medical Journal of Babylon. 2012;9(4):721-7.

2. Cooper DS. Antithyroid drugs. New England Journal of Medicine. 2005;352(9):905-17.

3. Dutta P, Bhansali A, Walia R, Khandelwal N, Das S, Masoodi SR. Weight homeostasis \& its modulators in hyperthyroidism before \& after treatment with carbimazole. The Indian journal of medical research. 2012;136(2):242.

4. Frieden E. Chemical endocrinology: Elsevier; 2012.

5. Ferreira E, Silva A, Serakides R, Gomes A, Cassali GD. Model of induction of thyroid dysfunctions in adult female mice. Arquivo Brasileiro de Medicina Veterinária e Zootecnia. 2007;59(5):1245-9.

6. Ferreira A, Lisboa P, Oliveira K, Lima L, Barros I, Carvalho D. Inhibition of thyroid type 1 deiodinase activity by flavonoids. Food and chemical toxicology. 2002;40(7):913-917.

7. Gonçalves CFL, dos Santos MCdS, Ginabreda MG, Fortunato RS, de Carvalho DP, Ferreira ACF. Flavonoid rutin increases thyroid iodide uptake in rats. PloS one. 2013;8(9):e73908.

8. Manna D, Roy G, Mugesh G. Antithyroid drugs and their analogues: synthesis, structure, and mechanism of action. Accounts of chemical research. 2013;46(11):2706-2715.

9. Mullur R, Liu Y-Y, Brent GA. Thyroid hormone regulation of metabolism. Physiological reviews. 2014;94(2):355-82.

10. Rajab NMA, Ukropina M, Cakic-Milosevic M. Histological and ultrastructural alterations of rat thyroid gland after short-term treatment with high doses of thyroid hormones. Saudi journal of biological sciences. 2017;24(6):1117-25.

11. Robert KM, Bender DA, Botham KM, Kennelly PJ, Rodwell VW, Weil PA. Harper's Illustrated Biochemistry (29e ed.)2016.

12. Sahoo DK, Roy A, Chainy GB. Protective effects of vitamin E and curcumin on L-thyroxine-induced rat testicular oxidative stress. Chemico-biological interactions. 2008;176(2-3):121-8.

13. Sangeeta, N.; Ajitkumar, S.; Prabita, D.; Ranjan, S.; Chubalemla, L.; Abhishek, D.; Gomi, Basar.; Ibahunlang, R.; Omita, D.; Amuba, S. (2016). Lipid Profile in Thyroid Dysfunction Patients. IOSR Journal of Dental and Medical Sciences (IOSR-JDMS) Volume 15, Issue 12 Ver. XI, PP 39-43.

14. Sharma G, Tyagi AK, Singh RP, Chan DC, Agarwal R. Synergistic anti-cancer effects of grape seed extract and conventional cytotoxic agent doxorubicin against human breast carcinoma cells. Breast cancer research and treatment. 2004;85(1):1-12.

15.Treesh S, Khair N. Effect of Thyroid Disorders on the Adult Female Albino Rats (Histological and Histochemical Study). Journal of Cytology \& Histology. 2014;5(4):1. 
16. Uduak OA, Ani EJ, Etoh ECI, Macstephen AO. Comparative effect of Citrus sinensis and carbimazole on serum T4, T3 and TSH levels. Nigerian medical journal: journal of the Nigeria Medical Association. 2014;55(3):230.

17. Vayupharp B, Laksanalamai V. Recovery of antioxidants from grape seeds and its application in fried food. Journal of Food Processing and Technology. 2012;3(4).

18. Zhang J, Lazar MA. The mechanism of action of thyroid hormones. Annual review of physiology. $2000 ; 62$. 